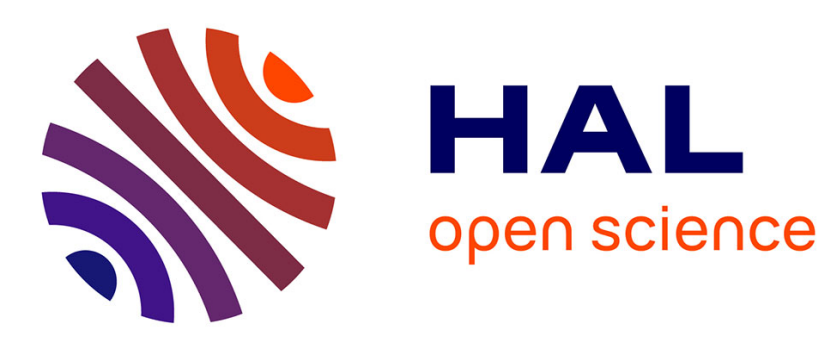

\title{
A combination of absorption and enzymatic biodegradation phenol elimination from aqueous and organic phase
}

Nassima Tandjaoui, Mahmoud Abouseoud, Annabelle Couvert, Abdeltif Amrane, Amina Tassist

\section{To cite this version:}

Nassima Tandjaoui, Mahmoud Abouseoud, Annabelle Couvert, Abdeltif Amrane, Amina Tassist. A combination of absorption and enzymatic biodegradation phenol elimination from aqueous and organic phase. Environmental Technology, 2019, 40 (5), pp.625-632. 10.1080/09593330.2017.1400110 . hal01812460

HAL Id: hal-01812460

https://hal-univ-rennes1.archives-ouvertes.fr/hal-01812460

Submitted on 22 Jun 2018

HAL is a multi-disciplinary open access archive for the deposit and dissemination of scientific research documents, whether they are published or not. The documents may come from teaching and research institutions in France or abroad, or from public or private research centers.
L'archive ouverte pluridisciplinaire HAL, est destinée au dépôt et à la diffusion de documents scientifiques de niveau recherche, publiés ou non, émanant des établissements d'enseignement et de recherche français ou étrangers, des laboratoires publics ou privés. 


\section{A combination of absorption and enzymatic biodegradation: phenol elimination from aqueous and organic phase.}

TANDJAOUI Nassima ${ }^{\mathrm{a}, \mathrm{c}^{*}}$, ABOUSEOUD Mahmoud ${ }^{\mathrm{a}, \mathrm{b}}$, COUVERT Annabelle $\mathrm{e}^{\mathrm{c}, \mathrm{d}}$, AMRANE Abdeltif $^{\mathrm{c}, \mathrm{d}}$,TASSIST Amina ${ }^{\mathrm{b}}$.

${ }^{a}$ Laboratoire de Biomatériaux et Phénomènes de Transport, Faculté des Sciences et de la Technologie, Université Yahia Fares de Médéa, Pole Universitaire, RN1, Médéa 26000,Algérie.

${ }^{b}$ Laboratoire de Génie de la Réaction, Faculté de Gênie Mécanique et Génie des Procédés, Université Houari Boumediene, Bab Ezzouar, Alger, 16111.

${ }^{\mathrm{c}}$ Ecole Nationale Supérieure de Chimie de Rennes, CNRS, UMR 6226, Avenue du Général Leclerc, CS 50837, 35708 Rennes Cedex 7, France.

${ }^{d}$ Université européenne de Bretagne, 5 Boulevard Laennec, 35000 Rennes, France.

* Corresponding author Dr.TANDJAOUI Nassima

Laboratoire de Biomatériaux et Phénomènes de Transport, Faculté des Sciences et de la Technologie, Université de Médéa, Pole Universitaire, RN1, Médéa 26000, Algérie.

Ecole Nationale Supérieure de Chimie de Rennes, CNRS, UMR 6226, 11 Allée de Beaulieu, CS 50837, 35708 Rennes Cedex 7, France. 
Tel/Fax : +213777561340/+21325581687

E-mail :<nassima_2900@yahoo.fr $>$;

\begin{abstract}
Peroxidase from Brassica rapa (BRP) was immobilized as cross-linked enzyme aggregates (CLEAs) and used to treat air containing phenol as a model molecule of volatile organic compounds (VOCs). Prior to enzymatic treatment, phenol was absorbed into aqueous or organic phase (silicone oil, Rhodorsil $\AA^{\circledR} 47 \mathrm{~V} 20$ ) to reach concentrations ranging from 20 to $160 \mathrm{mg} / \mathrm{L}$. The process of enzymatic degradation was carried out by introducing a desired weighing of BRP-CLEAs into preparations and reaction was started by injecting $\mathrm{H}_{2} \mathrm{O}_{2}$ solution to medium.

Optimization of the reaction conditions in the organic solvent revealed an optimal contact time of $60 \mathrm{~min}, 60 \mathrm{mg} / \mathrm{L}$ initial phenol concentration and $3 \mathrm{mM} \mathrm{H}_{2} \mathrm{O}_{2}$, leading to a maximum phenol removal yield of $70 \%$ for $\quad 3.4 \mathrm{UI} / \mathrm{mL}$ of BRP-CEEAs. These results were compared to those obtained in aqueous medium that showed $90 \%$ of VOC degradation yield after 40 min in the following conditions, $90 \mathrm{mg} / \mathrm{L}$ initial phenol amount, $2 \mathrm{mM}$ of $\mathrm{H}_{2} \mathrm{O}_{2}$ and an enzyme activity of $2.5 \mathrm{UI} / \mathrm{mL}$. Parameters of the Michaelis-Menten model, $K_{m}$ and $V_{\max }$, were also determined for the reaction of phenol degradation by BRP-CLEAs in both silicone oil and water. Phenol removal by Brassica rapa cross-linked enzyme in silicone oil succeeded with $70 \%$ of conversion yield. It is promising regarding the transposition of such enzymatic process to hydrophobic VOCs.
\end{abstract}

Keywords: BRP-CLEAs; Silicone oil; absorption; aqueous medium; biodegradation.

\title{
Introduction
}

The increasing development of industrial processes generate a variety of molecules that may pollute air and waters due to negative impacts for ecosystems and humans (toxicity, carcinogenic and mutagenic properties) [1]. Among these pollutants, volatile organic compounds (VOCs) and odorous compounds discharged into the environment represent a potential source of danger [2].

Phenol is considered as a volatile organic compound with a vapour pressure of $42.93 \mathrm{~Pa}$ at $25^{\circ} \mathrm{C}[3,4]$. Due to its toxicity, it has been classified as a priority pollutant by environmental 
institutions [5-7]. The US National Institute of Occupational Safety and Health (NIOSH) fixed the concentration immediately dangerous to life or health at $250 \mathrm{ppm}$ [8], while the US Environmental Protection Agency has established a provisional Reference Concentration for phenol of 0.006 milligrams per cubic meter in air [7]. As other VOCs, phenol is released into the air through a variety of industrial activities, such as synthetic resins, petrochemical, petroleum refineries, steel mills, coke oven plants, coal gas, pharmaceuticals, paints, plywood industries and mine discharge $[1,9]$.

The EC legislations and regulations on air quality and waste air treatment are being more and more serious regarding polluting industries [10], due to the high increase of risk and their consequences on human's health. An effective process of waste air treatment efficient for all pollutants does not exist, every VOC has been the subject of a single study, but despite of its toxicity, very few data can be found in the literature concerning the treatment of phenolcontaining gaseous streams [1]. Numerous remediation methods have been developed for the removal and decomposition of VOCs, taking the example of biodegradation by microorganisms [11], biofiltration [12-14], advanced oxidation processes [15,16], and finally absorption into liquids. The key variable of this last process is the choice of a suitable liquid absorbent. For instance, in the case of hydrophobic VOCs, water is not the most appropriate solvent and hence other absorbents are required [17]. Regarding phenol, according to its polarity and their partial reciprocal solubility, water can be chosen to remove phenol from gaseous streams by using 3 to $20 \%$ of sodium hydroxide solution as a scrubbing agent. Due to the weak acidity of phenol and the large solubility of sodium phenate in water, the process has revealed its weakness as important quantities of phenate-containing wastewater should be disposed or treated [1]. More recent studies revealed that silicone oils show high capacity to absorb VOCs from air or water [18]. Silicone oils also display certain characteristics which are selection criteria of choice for absorbents, such as low volatility, thermal and chemical stability and high absorption capacity [19-21]. In addition to the absorption step, VOC biodegradation was considered to allow solvent regeneration and hence the recycling of the VOC-free solvent owing to its cost. This biodegradation step was performed in a two partitioning phase bioreactor (TPPB) involving an aqueous phase containing microorganisms [22]. Nevertheless, the combined process coupling absorption and biodegradation presents some kind of complexity and side problems which could limit its applicability [23].

An alternative to the TPPB was examined in this study, which consisted to test an enzymatic process in place of the microbial degradation. In addition, the performances of the enzymes 
for phenol degradation were tested in both aqueous and organic phases to examine if the presence of water can be totally avoided and hence if only one liquid phase can be used for both steps of the combined process, absorption and enzymatic biocatalysis.

Phenol was considered in this study as a model VOC compound owing to its wide industrial use and since the enzymatic degradation of phenol by peroxidases in the presence of hydrogen peroxide is among the most studied subjects in the field of enzymatic processes in recent years [24-27]. The process presents many advantages, such as simplicity under mild conditions, high turn-over, selectivity, less drawbacks when compared to chemical processes and lower cost.

Peroxidase (EC 1.11.1.7) can be extracted from several sources, but the most studied one is horseradish Peroxidase (HRP), while other sources such as Brassica rapa showed great capacities as shown for the degradation of recalcitrant compounds including phenol [28-31]. Peroxidases were also successfully considered after immobilization on an appropriate support to eliminate phenol from aqueous streams [32-34]. The purpose of its use under immobilized form is to enhance its stability, recovery, selectivity and to reduce the inhibition by the medium or products [35]. A novel, practical and inexpensive immobilization technique has been developed by Sheldon et al [36], which has been named, cross-linked enzyme aggregates (CLEAs). It combines two unit processes, purification and immobilization, into a single operation. CLEAs have attracted increasing attention, due to their simplicity, broad applicability, long conservation and high stability in organic solvents [36-39]. The last characteristic is the main issue which could be exploited in the design of an integrated process (Absorption/enzymatic biocatalysis) for phenol degradation as a proof of feasibility towards VOCs treatment.

The main purpose of this work was therefore to study the degradation of phenol by BRPCLEAs in an organic phase (silicone oil) and to compare to that observed in an aqueous phase. In this aim, the impact of phenol and hydrogen peroxide concentrations, as well as enzyme activity, on the overall degradation kinetic were examined, with the objective of finding the optimal conditions under which the maximum yield of phenol removal could be achieved.

\section{Materials and Methods}

\section{Chemicals and Reagents}


Glutaraldehyde (25\% solution), Hydrogen peroxide aqueous solution (30\% w/w), guaiacol (98\%) were of analytical grade and obtained from Sigma-Aldrich (Germany). Phenol 99\% and sodium phosphate used for the preparation of buffer solution were purchased from Merck (Germany). The analytical reagents like 4-aminoantipyrine (4-AAP) and potassium ferricyanide were obtained from Sigma Aldrich (Germany).

Silicone oil (polydimethylsiloxane), Rhodorsil ${ }^{\circledR}$ 47V20 was purchased from the Rhodia Company, France. Table 1 summarises its main chemical and physical properties [40].

\section{BRP-CLEAs Preparation}

BRP-CLEAs were prepared as described in our previous work [41]. When needed, peroxidase was freshly prepared by squeezing some Brassica rapa turnip fruits of about $15 \mathrm{~cm}$; a specific dilution of $3 / 4$ of the filtrate with phosphate buffer was prepared and then directly precipitated using acetone. The mixture was subsequently cross-linked using glutaraldehyde solution $(25 \%)$ at a concentration of $2 \%(\mathrm{~V} / \mathrm{V})$. Aggregated enzymes (CLEAs) were finally separated using centrifugation; then thoroughly washed with distilled water and stored in phosphate buffer $(50 \mathrm{mM})(\mathrm{pH}=7)$ at $4^{\circ} \mathrm{C}$ until use.

\section{The activity assay of BRP-CLEAs}

The guaiacol colorimetric assay was used for measuring BRP-CLEAs activity [42]. The reaction mixture consisted of $4.05 \mu \mathrm{L}$ of $98 \%$ guaiacol, $2 \mathrm{mg}$ of CLEAs, $3.9 \mathrm{ml}$ of phosphate buffer $(50 \mathrm{mM}, \mathrm{pH}=7)$. The reaction was started by the addition of $5 \mu 1$ of $\mathrm{H}_{2} \mathrm{O}_{2}(0.8 \mathrm{M})$, ending up with a volume of $4 \mathrm{~mL}$. The initial rate of colour formation at a wavelength of 470 $\mathrm{nm}$ was monitored using a SHIMADZU UV-VIS spectrophotometer model UV mini-1240 and a molar extinction coefficient of $4279 \mathrm{M}^{-1} \cdot \mathrm{cm}^{-1}$. The BRP-CLEAs activity was checked regularly before use in phenol biodegradation assays.

\section{Phenol absorption into silicone oil (Rhodorsil ${ }^{\circledR}$ 47V20)}

In order to generate the contaminated phase of silicone oil by the waste air stream of phenol, a laboratory model was adopted by dissolving a specific amount of phenol in Rhodorsil ${ }^{\circledR}$ $47 \mathrm{~V} 20$, to achieve a final concentration of $1000 \mathrm{mg} / \mathrm{L}$, the solution was kept under magnetic agitation for 2 hours at $50^{\circ} \mathrm{C}$ until all phenol crystals were dissolved. This preparation was considered as a stock solution for preparing further diluted solutions. It was conserved in a dark bottle at $4^{\circ} \mathrm{C}$. In order to check its conservation, a calibration curve of phenol 
concentration was daily established using phenol UV absorption method as described below ('Analytical methods' sub-section). The extinction coefficient was also determined.

\section{Phenol removal with the BRP-CLEAs}

Batch experiments were conducted to remove phenol from silicone oil HV20 as follows: reactions were carried out in $20 \mathrm{~mL}$ volumetric vials equipped with a magnetic stirrer and closed with PTFE-coated silicone rubber septa (PerkinElmer, France) sealed with aluminium caps. The mixtures consisted of $5 \mathrm{~mL}$ of silicone oil containing a specific concentration of phenol which was added from the stock solution. BRP-CLEAs $(5 \mathrm{mg})$ were added to each vial. The reaction was initiated by adding hydrogen peroxide $(5 \mu \mathrm{L})$ using a micro-syringe of $25 \mu \mathrm{L}$ through the rubber septa. The vials were maintained at room temperature $\left(25 \pm 3^{\circ} \mathrm{C}\right)$ under $600 \mathrm{rpm}$ magnetic stirring to keep CLEAs permanently dispersed in the silicone oil phase during the reaction time.

Similarly, phenol degradation in aqueous environment was studied using a phosphate buffer solution $(\mathrm{pH}=7,10 \mathrm{mM})$ as reaction medium. Other conditions were kept the same as described above using silicone oil as the liquid phase. At the end of the reaction, the solutions were centrifuged at $5000 \mathrm{rpm}$ and the supernatant was assessed for residual phenol amount.

Aiming to maximize phenol degradation yield in both silicone oil and aqueous medium, the kinetics of phenol degradation was followed under different experimental conditions, namely various initial phenol concentrations in the range 20 to $160 \mathrm{mg} / \mathrm{L}$, hydrogen peroxide from 0.5 to $20 \mathrm{mM}$ and BRP-CLEAs amounts from 2.5 to $20 \mathrm{mg}$ corresponding to an activity of 0.4 to $5 \mathrm{UI} / \mathrm{mL}$.

Two parameters were considered to assess for the efficiency of phenol removal in both phases, silicone oil and aqueous phase, the conversion yield and the initial rate $\left(\mathrm{V}_{0}\right)$, which was determined by extrapolating the slope of the time course of the substrate concentration at initial time.

Experiments were performed in triplicate. Control experiments were done under the same conditions in organic or aqueous phases free from BRP-CLEAs then free from $\mathrm{H}_{2} \mathrm{O}_{2}$ to estimate the abiotic degradation of phenol.

\section{Analytical methods}

Residual phenol concentration in silicone oil was determined by direct analysis at the maximum absorbance wavelength of phenol $(270 \mathrm{~nm})$ using a UV-Vis spectrophotometer, 
against a blank of silicone oil. Residual concentration of phenol was determined by using an appropriate calibration curve previously established with an extinction coefficient of $\varepsilon_{1}=$ $0.016 \mathrm{~L} / \mathrm{mg}$.

In aqueous solution, residual phenol was determined using a colorimetric assay in which the phenolic compounds within a sample reacts with 4-AAP in the presence of potassium ferricyanide reagent under alkaline conditions [43-45]. The procedure was as follows: a sample of $2.4 \mathrm{~mL}$ from the treated solution was withdrawn using a syringe and diluted with phosphate buffer (pH7) (phenol concentration up to $0.2 \mathrm{mM}$ ). The mixture was then added to $0.3 \mathrm{~mL}$ of potassium ferricyanide $(83.4 \mathrm{mM})$ and $0.3 \mathrm{~mL}$ of 4 -AAP $(20.8 \mathrm{mM})$, and the mixture absorbance was measured after few minutes at $510 \mathrm{~nm}$ using an extinetion coefficient of $\varepsilon_{2}=9.8 \times 10^{-3} \mathrm{~L} / \mathrm{mg}$.

\section{Results and Discussion}

The BRP-CLEAs were prepared according to a method previously described [41]; and it was proved that they were quite stable in 47HV20 silicone oil which was encouraged for use in the considered absorption/enzymatic degradation process. The prepared CLEAs had a relative activity of $0.82 \mathrm{UI} / \mathrm{mg}$.

\section{Effect of the phenol concentration}

The kinetics of any enzymatic reaction are affected by substrate concentration. Figure 1(a) and 1(b) show the evolution of phenol concentration with time. At constant peroxide and enzyme concentration, the effect of the initial phenol concentration $\left(C_{0}\right)$ on the initial rate $V_{0}$ and conversion yield (\%), is reported in Figure 1(c) and 1(d). It is clear that $\mathrm{V}_{0}$, as well as the removal yield, depend on the initial substrate concentration $\left(\mathrm{C}_{0}\right)$. Similar remarks could be drawn for both aqueous and organic media. The curves of initial phenol concentration versus first reaction rate $\mathrm{V}_{0}$ show that the rate increased rapidly and linearly at low phenol concentrations, but it gradually tended towards a limiting value at high concentrations of the substrate. A slight decrease in $\mathrm{V}_{0}$ for phenol concentrations higher than $120 \mathrm{mg} / \mathrm{L}$ in silicone oil was found. In this region, all the enzyme molecules are bound to the substrate molecules, and the rate becomes zero order in substrate concentration. The optimal values of concentration of phenol were defined as $90 \mathrm{mg} / \mathrm{L}$ and $60 \mathrm{mg} / \mathrm{L}$ in aqueous phase and silicone oil, respectively. 
At fixed hydrogen peroxide concentration and activity, the reaction proceeded faster in aqueous phase (40 min) than in silicone oil (60 min) (Figure 1(a) and 1(b)).

Although phenol degradation in the organic solvent, silicone oil (47V20), did occur with BRP-CLEAs as a catalyst, only $15 \%$ of removal was achieved after one hour when phenol concentration was $60 \mathrm{mg} / \mathrm{L}$. Another phenomenon which altered negatively the degradation in the organic solvent was the accumulation of product degradation on the surface of BRPCLEAs, which limited the access of the substrate to the active sites and the overall reaction rate $[46,47]$.

It was an expected result due to mass transfer limitations in the organic phase lowering the total activity of the enzyme $[38,48,49]$. Another explanation could be added which is based on solvent-substrate interactions which could lower the free energy of the substrate and thereby its reactivity. Rhodorsil ${ }^{\circledR} 47 \mathrm{~V} 20$, a nonpolar solvent, dissolves phenol very efficiently lowering the free energy, decreasing consequently the rate of the reaction. The solvent also influences the equilibrium position of reactions, and hence the solvation of both substrates and products must be considered [50].

\section{Kinetic parameters}

To evaluate the effect of the silicone oil on the kinetics of phenol degradation by BRPCLEAs, the Michaelis-Menten model was adopted and values $\left(K_{\mathrm{m}}, V_{\max }\right)$ were determined using the Lineweaver-Burk double reciprocal plot (Equation (1)) in each phase (Figures. 2(a), 2(b)).

$\frac{1}{s_{0}}=\frac{1}{V_{\max }}+\frac{K_{m}}{V_{\max }} \times \frac{1}{[\text { Phenol }]_{0}}$

The apparent half-saturation constant $\left(K_{\mathrm{m}}\right)$ value reflects the affinity of the BRP-CLEAs for phenol. An enzyme with a high $K_{\mathrm{m}}$ has a low affinity for its substrate [51], whereas $V_{\max }$ is considered as the maximal rate at which a reaction could proceed. It is evident from table 2 that $K_{m}$ is affected by the nature of the solvent. The lower $K_{m}$ value obtained in silicone oil indicated a better affinity of BRP-CLEAs to phenol. However, the ratio $V_{\max } / K_{m}$, which characterizes the specificity of the enzyme to the substrate the larger the ratio, the more effective is the substrate utilization by the enzyme) [52], was in favor of the aqueous medium. Nevertheless, this could lead to false conclusions since theses parameters are only apparent values regarding mass transfer limitations occurring with immobilized enzyme.

\section{Effect of the hydrogen peroxide concentration}


Figure 3 illustrates the effect of hydrogen peroxide concentration on the reduction of phenol concentration after 40 and 60 minutes of reaction time and for initial phenol concentration of $90 \mathrm{mg} / \mathrm{L}$ and $60 \mathrm{mg} / \mathrm{L}$ in aqueous phase and silicone oil, respectively. Hydrogen peroxide concentration in the reaction medium was varied by injecting four times volumes of $5 \mu \mathrm{L}$ every 10 minutes in aqueous phase and every 15 minutes in silicone oil from freshly prepared peroxide solutions.

For the investigated range of hydrogen peroxide concentrations $(0.5-20 \mathrm{mM})$, the rate and the percentage of phenol conversion increased with the peroxide concentration to reach an optimum between 2 to $3 \mathrm{mM}$ of $\mathrm{H}_{2} \mathrm{O}_{2}$ in the case of aqueous phase (Figure 3(a)); Maximal conversion was about 60 to $65 \%$ for an initial rate of $1.41 \mathrm{mg} / \mathrm{L}$.min. While in the case of silicone oil, maximum conversion was about $40 \%$ for a lower initial rate $0.41 \mathrm{mg} / \mathrm{L} \mathrm{min}$ at a concentration of $3 \mathrm{mM} \mathrm{H}_{2} \mathrm{O}_{2}$ (Figure 3(b)).

At peroxide concentrations higher than the optimal values detected in both phases, the rate and the yield of phenol conversion decreased dramatically. This decrease was most likely due to a deactivating effect of the hydrogen peroxide on peroxidase that irreversibly oxidize the enzyme ferriheme group essential for peroxidase activity [53] or to the fact that an excess of peroxide produces more intermediate products which inhibit the activity of the enzymes [32]. This result was an agreement with some studies dealing with phenol removal by peroxidise $[54,55]$. The above results show that the adequate molar ratio of hydrogen peroxide dose to the initial phenol concentration $\left(\left[\mathrm{H}_{2} \mathrm{O}_{2}\right] /[\mathrm{Phenol}]\right)$ is $2: 1$ in aqueous phase and $4: 1$ in silicone oil (47V20); from this, BRP-CLEAs require a higher dose of hydrogen peroxide in organic medium compared to that needed in aqueous phase.

\section{Effect of the BRP-CLEAs activity}

The fourth parameter that could enhance the reaction of phenol degradation is the BRPCLEAs concentration or activity in the reaction medium. All above experiments were carried out with a constant mass of enzyme $5 \mathrm{mg}(\approx 0.86 \mathrm{UI} / \mathrm{mL})$. To examine the impact of the BRPCLEAs concentration, the molar ratio of phenol to hydrogen peroxide was kept constant at its optimal value, 1:2 in aqueous phase and 1:4 in silicone oil, and the enzyme activity was varied from 0.4 to $4.5 \mathrm{UI} / \mathrm{mL}$ by weighing the correspondent amount of BRP-CLEAs. Results obtained in both solvents are represented in (Figure 4). It is important to note that increasing the BRP-CLEAs amount in silicone oil was faced with the problem of their dispersion. In 
order to avoid this problem and to ensure a good homogeneity of the system, the mixture was sonicated in ultrasound bath for 15 minutes at $25^{\circ} \mathrm{C}$ prior to peroxide injection. Data elucidate that enzyme concentration has a significant effect on phenol degradation in both solvents. The reaction rate increased rapidly when the concentration raised from 0.4 to $2.0 \mathrm{UI} / \mathrm{mL}$ in aqueous phase and from 0.5 to $2.8 \mathrm{UI} / \mathrm{mL}$ in silicone oil. This result was predictable since the availability of enzyme sites induce an attraction of substrate molecules and subsequently an increase in the number of molecules converted per unit of time.

Maximum performance of BRP-CLEAs was achieved at an optimal concentration of 2.5 $\mathrm{UI} / \mathrm{mL}$ and $3.4 \mathrm{UI} / \mathrm{mL}$ in aqueous phase and organic solvent, respectively. While, increasing the enzyme concentration beyond these points had no noticeable effect because the substrate concentration became the limiting factor.

The conditions under which maximum phenol removal was achieved by BRP-CLEAs are summarized in Table 3.

\section{Conclusion}

Coupling absorption to enzyme conversion seems to be a promising new technique for the removal of hydrophobic compounds, which could be first absorbed in a suitable solvent containing the specific enzyme in the appropriate form. Results of the present study showed the feasibility of the process of phenol removal by Brassica rapa cross-linked enzyme into silicone oil. It was demonstrated that the process is significantly affected by substrate and enzyme concentrations which were optimized to obtain a maximal degree of phenol elimination. Mass transfer limitations and solvent-enzyme-substrate interactions are to be considered and well understood prior to any industrial process design calculations. These promising results also open new and promising perspectives towards the transposition of such enzymatic process to hydrophobic VOCs. 


\section{References}

[1] Busca G, Berardinelli S, Resini C, et al. Technologies for the removal of phenol from fluid streams: A short review of recent developments. J. Hazard. Mater. 2008;160:265288.

[2] Parker DB, Cai L, Kim K-H, et al. Reducing odorous VOC emissions from swine manure using soybean peroxidase and peroxides. Bioresour. Technol. 2012;124:95104.

[3] Ni J-Q, Robarge WP, Xiao C, et al. Volatile organic compounds at swine facilities: A critical review. Chemosphere. 2012;89:769-788.

[4] Wan-Ying Shiu, Kuo-Ching Ma, Dana Varhanickova, et al. Chlorophenols and Alkylphenols: A Review and Correlation of Environmentally Relevant Properties and Fate in an Evaluative Environment. Chemosphere. 1994;29:1155-1224.

[5] ATSDR,Agency for toxic Substances and Disease Registry ATSDR - Priority List of Hazardous Substances [Internet]. 2013 [cited 2015 Jul 14]. Available from: http://www.atsdr.cdc.gov/spl/.

[6] NIOSH,The National Institute for Occupational Safety and Health. CDC - NIOSH Pocket Guide to Chemical Hazards (NPG) [Internet]. 2005 [cited 2015 Jul 18]. Available from: http://www.cdc.gov/niosh/npg/.

[7] US EPA. Phenol | Technology Transfer Network Air Toxics Web site | US EPA [Internet]. 2013 [cited 2015 Jul 13]. Available from: http://www.epa.gov/ttn/atw/hlthef/phenol.html.

[8] NIOSH , The National Institute for Occupational Safety and Health. CDC - Immediately Dangerous to Life or Health Concentrations (IDLH): Chemical Listing and Documentation of Revised IDLH Values - NIOSH Publications and Products [Internet]. 1995 [cited 2015 Jul 18]. Available from: http://www.cdc.gov/niosh/idlh/intridl4.html.

[9] Moussayi G, Mohseni M. The treatment of waste air containing phenol vapors in biotrickling filter. Chemosphere. 2008;72:1649-1654.

[10] EC, European Comission. Directive 2008/50/EC of the European parliament and of the council of 21 may 2008 on ambient air quality and cleaner air for Europe. Off. J Eur. Union. 2008;1-44.

[11] Qi B, Moe WM, Kinney KA. Biodegradation of volatile organic compounds by five fungal species. Appl. Microbiol. Biotechnol. 2002;58:684-689.

[12] He Z, Zhou L, Li G, et al. Comparative study of the eliminating of waste gas containing toluene in twin biotrickling filters packed with molecular sieve and polyurethane foam. J. Hazard. Mater. 2009;167:275-281.

[13] Ikemoto S, Jennings A, Skubal K. Modeling hydrophobic VOC biofilter treatment in the presence of nutrient stimulation and hydrophilic VOC inhibition. Environ. Model. Softw. 2006;21:1387-1401. 
[14] Moussavi G, Heidarizad M. Biodegradation of mixture of phenol and formaldehyde in wastewater using a single-basin MSCR process. J. Biotechnol. 2010;150:240-245.

[15] Burgos N, Paulis M, Mirari Antxustegi M, et al. Deep oxidation of VOC mixtures with platinum supported on A12O3/Al monoliths. Appl. Catal. B Environ. 2002;38:251-258.

[16] Walerczyk W, Zawadzki M. Structural and catalytic properties of Pt/ZnAl2O4 as catalyst for VOC total oxidation. Catal. Today. 2011;176:159-162.

[17] Heymes F, Manno-Demoustier P, Charbit F, et al. A new efficient absorption liquid to treat exhaust air loaded with toluene. Chem. Eng. J. 2006;115:225-231.

[18] Darracq G, Couvert A, Couriol C, et al. Silicone oil: An effective absorbent for the removal of hydrophobic volatile organic compounds. J. Chem. Technol. Biotechnol. 2010;85:309-313.

[19] Darracq G, Couvert A, Couriol C, et al. Optimization of the volume fraction of the NAPL, silicone oil, and biodegradation kinetics of toluene and DMDS in a TPPB. Int. Biodeterior. Biodegrad. 2012;71:9-14.

[20] Dumont E, Andrès Y, Le Cloirec P. Mass transfer coefficients of styrene and oxygen into silicone oil emulsions in a bubble reactor. Chem. Eng. Sci. 2006;61:5612-5619.

[21] Dumont E, Darracq G, Couvert A, et al. Determination of partition coefficients of three volatile organic compounds (dimethylsulphide, dimethyldisulphide and toluene) in water/silicone oil mixtures. Chem. Eng. J. 2010;162:927-934.

[22] Darracq G, Couvert A, Couriol C, et al. Removal of Hydrophobic Volatile Organic Compounds in an Integrated Process Coupling Absorption and BiodegradationSelection of an Organic Liquid Phase. Water. Air. Soil Pollut. 2012;223:4969-4997.

[23] Muñoz R, Daugulis AJ, Hernández M, et al. Recent advances in two-phase partitioning bioreactors for the treatment of volatile organic compounds. Biotechnol. Adv. $2012 ; 30: 1707-1720$.

[24] Bansal N, Kanwar SS. Peroxidase(s) in Environment Protection. Sci. World J. 2013,2013:1-9.

[25] Narayan AV, Agrawal P. Enzyme based processes for removal of phenol from waste water: current status and future challenges. J Env. Res Dev. 2012;2:724-728.

[26] Sukan A, Sargin S. Enzymatic Removal of Phenol from Industrial Wastewaters. J. Biomater. Nanobiotechnology. 2013;04:300.

[27] Satar R, Husain Q. Phenol-mediated decolorization and removal of disperse dyes by bitter gourd (Momordica charantia) peroxidase. Environ. Technol. 2009;30:1519-1527.

[28] Ahmedi A, Abouseoud M, Couvert A, et al. Enzymatic degradation of Congo Red by turnip (Brassica rapa) peroxidase. Z. Für Naturforschung C J. Biosci. 2012;67:429-436. 
[29] Azizi A, Abouseoud M, Ahmedi A. Phenol removal by soluble and algi nate entrapped turnip peroxidase. J Biochem Tech. 2014;4:795-800.

[30] Kulshrestha Y, Husain Q. Bioaffinity-based an inexpensive and high yield procedure for the immobilization of turnip (Brassica rapa) peroxidase. Biomol. Eng. 2006;23:291-297.

[31] Karim Z, Husain Q. Removal of benzidine from polluted water by soluble and immobilized peroxidase in batch processes and continuous horizontal bed reactor. Environ. Technol. 2011;32:83-91.

[32] Alemzadeh I, Nejati S. Phenols removal by immobilized horseradish peroxidase. J. Hazard. Mater. 2009;166:1082-1086.

[33] Gómez JL, Bódalo A, Gómez E, et al. Immobilization of peroxidases on glass beads: An improved alternative for phenol removal. Enzyme Microb. Technol. 2006;39:10161022.

[34] Vojinović V, Carvalho RH, Lemos F, et al. Kinetics of soluble and immobilized horseradish peroxidase-mediated oxidation of phenolic compounds. Biochem. Eng. J. 2007;35:126-135.

[35] Mateo C, Palomo JM, Fernandez-Lorente G, et al. Improvement of enzyme activity, stability and selectivity via immobilization techniques. Enzyme Microb. Technol. 2007;40:1451-1463.

[36] Sheldon RA. Cross-linked enzyme aggregates (CLEAs): stable and recyclable biocatalysts. Biochem. Soc. Trans. 35 62007 [Internet]. 2007 [cited 2015 Apr 20]; Available from: http///repository.tudelft.nl/view/ir/uuid:a3a99c38-5677-4695-a487c2b37551241e/.

[37] Cao L. Immobilised enzymes: science or art? Curr. Opin. Chem. Biol. 2005;9:217-226.

[38] Gupta MN, Mukherjee J, Malhotra D. Use of high activity enzyme preparations in neat organic solvents for organic synthesis. Univers. Org. Chem. 2013;1:1.

[39] Sheldon RA. Characteristic features and biotechnological applications of cross-linked enzyme aggregates (CLEAs). Appl. Microbiol. Biotechnol. 2011;92:467-477.

[40] Bluestar silicones. Rhodorsil ${ }^{\circledR}$ Huiles 47 Information technique. 2012.

[41] Tandjaoui N, Tassist A, Abouseoud M, et al. Preparation and characterization of crosslinked enzyme aggregates (CLEAs) of Brassica rapa peroxidase. Biocatal. Agric. Biotechnol. 2015;4:208-213.

[42] Egley GH, Jr RNP, Vaughn KC, et al. Role of peroxidase in the development of waterimpermeable seed coats in Sida spinosa L. Planta. 1983;157:224-232.

[43] Bayramoğlu G, Arıca MY. Enzymatic removal of phenol and p-chlorophenol in enzyme reactor: Horseradish peroxidase immobilized on magnetic beads. J. Hazard. Mater. 2008;156:148-155. 
[44] Bódalo A, Bastida J, Máximo MF, et al. A comparative study of free and immobilized soybean and horseradish peroxidases for 4-chlorophenol removal: protective effects of immobilization. Bioprocess Biosyst. Eng. 2008;31:587-593.

[45] Feng W, Taylor KE, Biswas N, et al. Soybean peroxidase trapped in product precipitate during phenol polymerization retains activity and may be recycled: SBP, EC 1.11.1.7 trapped in precipitate during phenol polymerization retains activity. J. Chem. Technol. Biotechnol. 2013;88:1429-1435.

[46] Tandjaoui N, Abouseoud M, Couvert A, et al. A new combined green method for 2Chlorophenol removal using cross-linked Brassica rapa peroxidase in silicone oil. Chemosphere. 2016;148:55-60.

[47] Zhang F, Zheng B, Zhang J, et al. Horseradish Peroxidase Immobilized on Graphene Oxide: Physical Properties and Applications in Phenolic Compound Removal. J. Phys. Chem. C. 2010;114:8469-8473.

[48] Adlercreutz P. Immobilisation and application of lipases in organic media. Chem. Soc. Rev. 2013;42:6406-6436.

[49] Hanefeld U, Gardossi L, Magner E. Understanding enzyme immobilisation. Chem Soc Rev. 2009;38:453-468.

[50] Adlercreutz P. Fundamentals of Biocatalysis in Neat Organic Solvents. Biocatal. Neat Org. Solvents - Fundam. John Wiley \& Sons; 2008. p. 3-24.

[51] Cheng W, Harper WF. Chemical kinetics and interactions involved in horseradish peroxidase-mediated oxidative polymerization of phenolic compounds. Enzyme Microb. Technol. 2012;50:204-208.

[52] Purich DL, Allison RD. Handbook of Biochemical Kinetics: A Guide to Dynamic Processes in the Molecular Life Sciences. Academic Press; 1999.

[53] Akhtar S, Husain Q. Potential applications of immobilized bitter gourd (Momordica charantia) peroxidase in the removal of phenols from polluted water. Chemosphere. 2006;65:1228-1235.

[54] Deva AN, Arun C, Arthanareeswaran G, et al. Extraction of peroxidase from waste Brassica oleracea used for the treatment of aqueous phenol in synthetic waste water. J. Environ. Chem. Eng. 2014;2:1148-1154.

[55] Masuda M, Sakurai A, Sakakibara M. Effect of reaction conditions on phenol removal by polymerization and precipitation using Coprinus cinereus peroxidase. Enzyme Microb. Technol. 2001;28:295-300. 


\section{Figure legends}

Figure 1.Effect of phenol concentration on the kinetics of enzymatic degradation by BRPCLEAs in aqueous phase $(a, c)$ and silicone oil $(b, d)$. Reaction mixture: $5 \mathrm{~mL}$ of silicone oil or phosphate buffer $(10 \mathrm{mM}), 5 \mu \mathrm{L}$ of $\mathrm{H}_{2} \mathrm{O}_{2}(1 \mathrm{M}), 5 \mathrm{mg}$ of CLEAs $(0.82 \mathrm{UI} / \mathrm{mL})$ at room temperature.

Figure 2. Lineweaver-Burk double reciprocal plot of phenol degradation by BRP-CLEAs in aqueous phase (a) and silicone oil (47V20) (b)

Figure 3. Effect of hydrogen peroxide concentration on phenol degradation using BRPCLEAs in aqueous phase (a) and silicone oil (b). Reaction mixture: $5 \mathrm{ml}$ of silicone oil or phosphate buffer $(\mathrm{pH}=7,10 \mathrm{mM}), 90 \mathrm{mg} / \mathrm{L}$ of phenol in aqueous phase and $60 \mathrm{mg} / \mathrm{L}$ in silicone oil (47 HV20), $5 \times 4 \mu \mathrm{L}$ of $\mathrm{H}_{2} \mathrm{O}_{2}, 5 \mathrm{mg}$ of CLEAs $(0.82 \mathrm{UI} / \mathrm{mL})$ at room temperature.

Figure 4. Effect of BRP-CLEAs on phenol degradation in aqueous phase (a) and silicone oil (b). Reaction mixture: $5 \mathrm{ml}$ of silicone oil or phosphate buffer $(\mathrm{pH}=7,10 \mathrm{mM}), 90 \mathrm{mg} / \mathrm{L}$ of phenol in aqueous phase and $60 \mathrm{mg} / \mathrm{L}$ in silicone oil (47HV20), $5 \times 4 \mu \mathrm{L}$ of $\mathrm{H}_{2} \mathrm{O}_{2}(2 \mathrm{mM}$ ) in aqueous phase and $(3 \mathrm{mM})$ in silicone oil at room temperature. 


\section{Tables legends}

Table 1. Chemical and physical properties of Rhodorsil $\AA$ 47V20.

Table 2. Kinetic constants of phenol degradation by BRP-CLEAs in aqueous phase and silicone oil (47V20)

Table 3. Optimal conditions for phenol removal by BRP-CLEAs in aqueous and organic media 

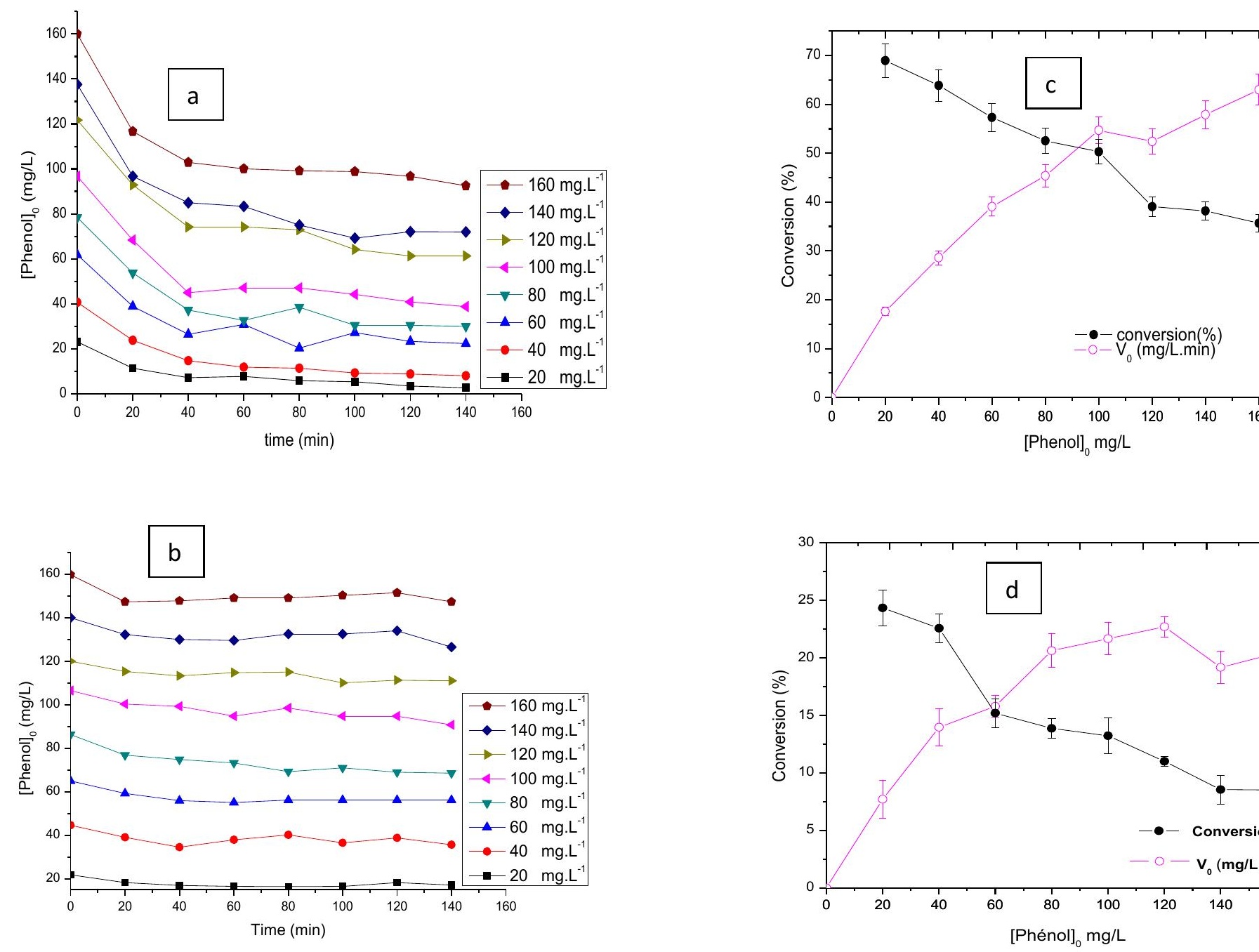

Figure 1.Effect of phenol concentration on the kinetics of enzymatic degradation by BRPCLEAs in aqueous phase $(\mathrm{a}, \mathrm{c})$ and silicone oil $(\mathrm{b}, \mathrm{d})$, Reaction mixture: $5 \mathrm{~mL}$ of silicone oil or phosphate buffer $(\mathrm{pH} 7,10 \mathrm{mM}), 5 \mu \mathrm{L}$ of $\mathrm{H}_{2} \mathrm{O}_{2}(1 \mathrm{M}), 5 \mathrm{mg}$ of CLEAs $(0.82 \mathrm{UI} / \mathrm{mL})$ at room temperature. 

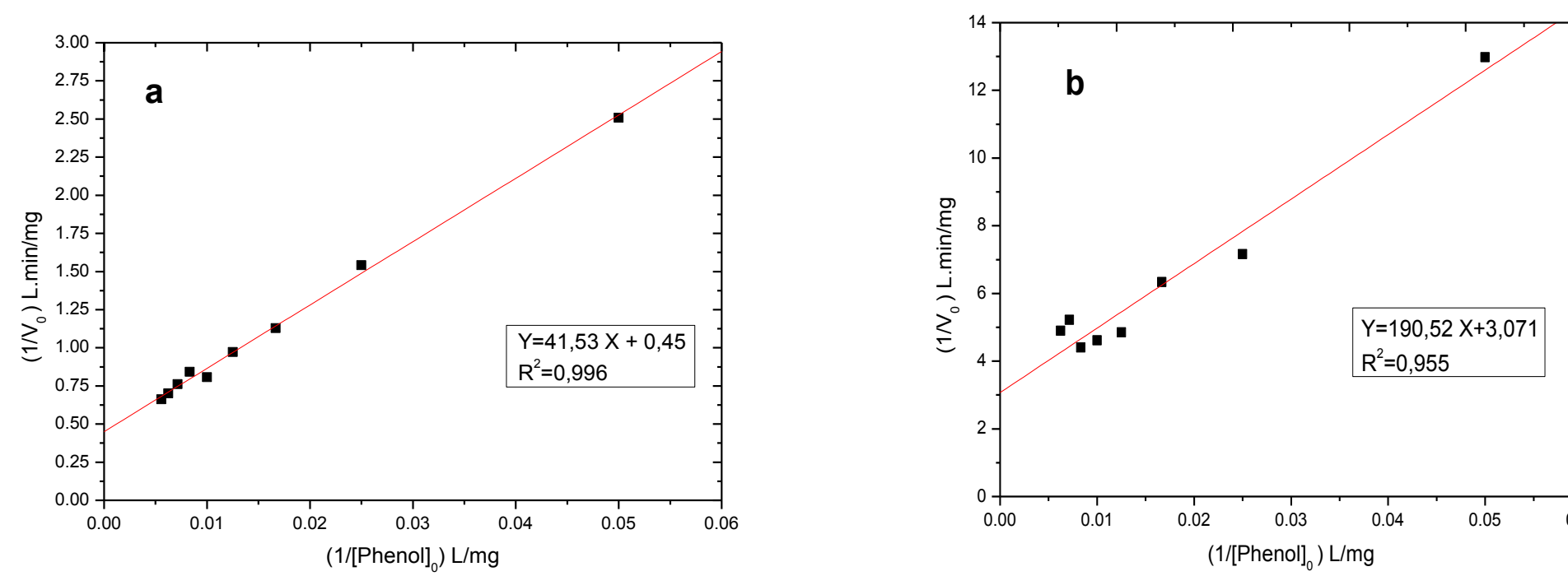

Figure 2. Lineweaver-Burk double reciprocal plot of phenol degradation by BRP-CLEAs in aqueous phase (a) and silicone oil (47V20) (b) 

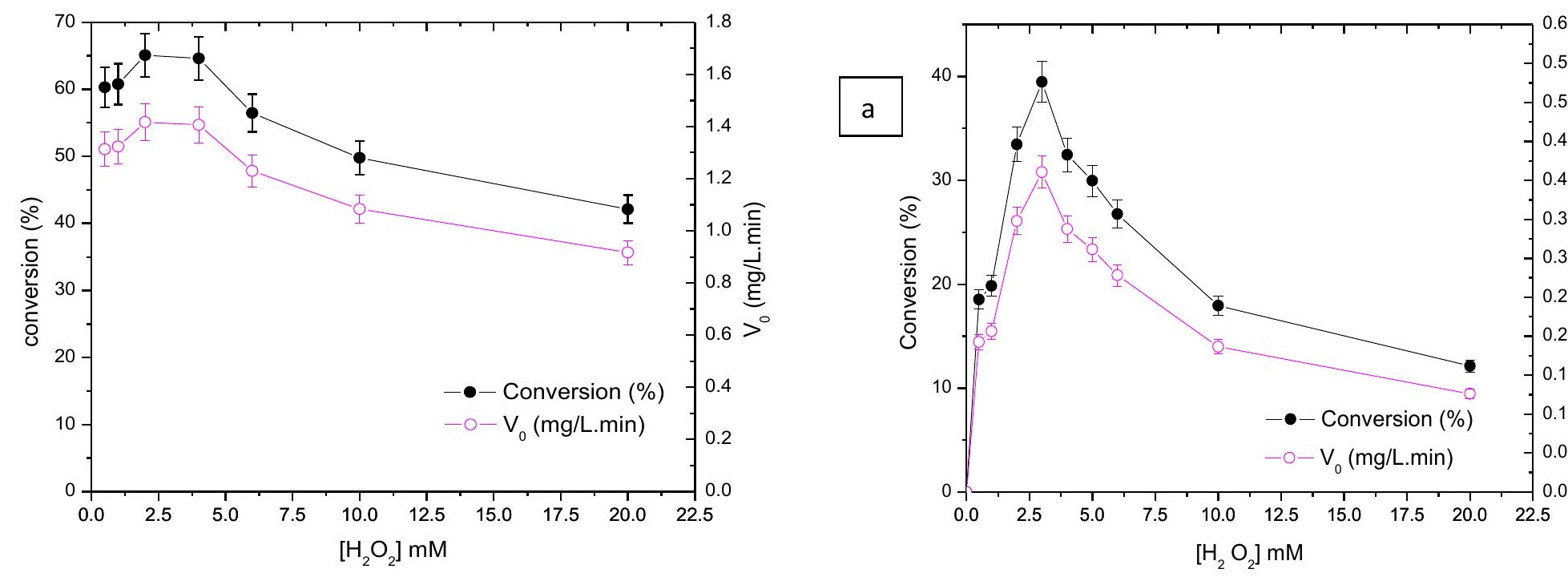

Fig. 3. Effect of hydrogen peroxide concentration on phenol degradation using BRP-CLEAs in aqueous phase (a) and silicone oil (b), Reaction mixture: $5 \mathrm{ml}$ of silicone oil or phosphate buffer $(\mathrm{pH}=7,10 \mathrm{mM}), 90 \mathrm{mg} / \mathrm{L}$ of phenol in aqueous phase and $60 \mathrm{mg} / \mathrm{L}$ in silicone oil (47 $\mathrm{HV} 20), 5 \times 4 \mu \mathrm{L}$ of $\mathrm{H}_{2} \mathrm{O}_{2}, 5 \mathrm{mg}$ of CLEAs $(0.82 \mathrm{UI} / \mathrm{ml})$ at room temperature. 

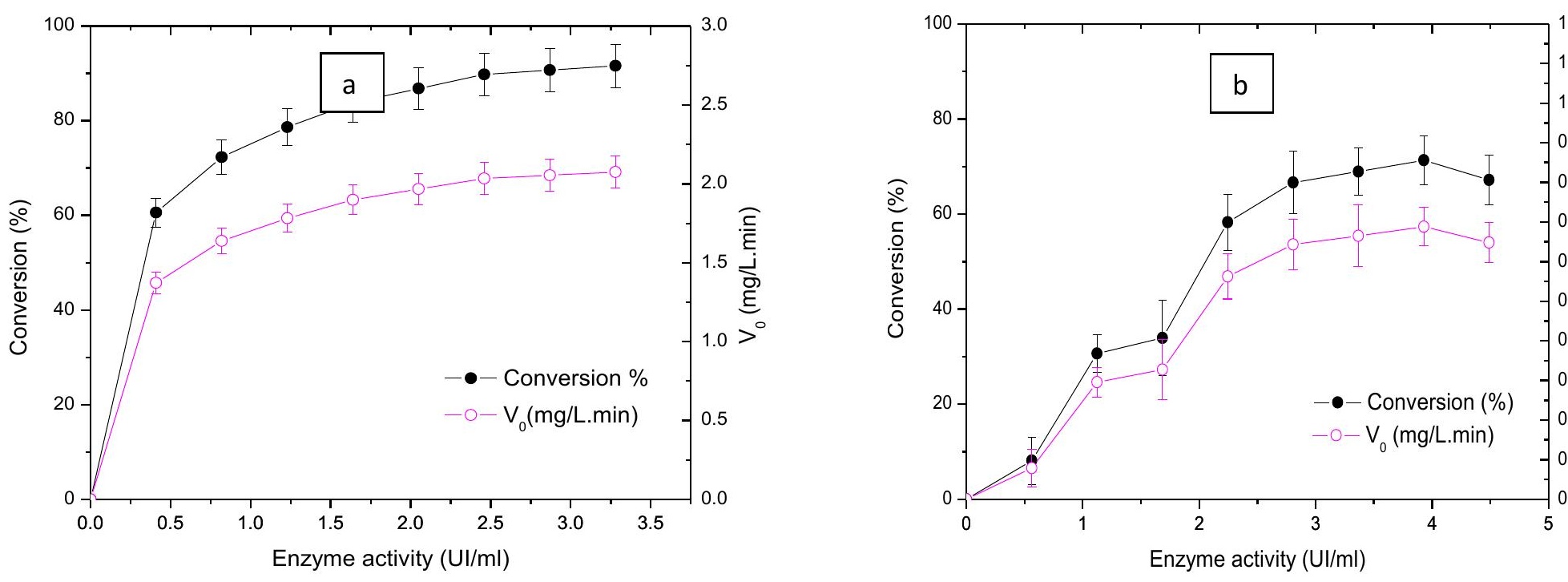

Fig. 4. Effect of BRP-CLEAs on phenol degradation in aqueous phase (a) and silicone oil (b) Reaction mixture: $5 \mathrm{ml}$ of silicone oil or phosphate buffer $(\mathrm{pH}=7,10 \mathrm{mM}), 90 \mathrm{mg} / \mathrm{L}$ of phenol in aqueous phase and $60 \mathrm{mg} / \mathrm{L}$ in silicone oil (47HV20), $5 \times 4 \mu \mathrm{L}$ of $\mathrm{H}_{2} \mathrm{O}_{2}(2 \mathrm{mM})$ in aqueous phase and $(3 \mathrm{mM})$ in HV20 at room temperature. 
Table 1. Chemical and physical properties of Rhodorsil ${ }^{\circ} 47$ V20.

\begin{tabular}{cc}
\hline Property & Value \\
\hline Molecular weight $(\mathrm{g} / \mathrm{mol})$ & 2800 to 3200 \\
Viscosity à $25^{\circ} \mathrm{C}(\mathrm{mPa})$ & 20 \\
Density at $25^{\circ} \mathrm{C}$ & 0.950 \\
Dielectric constant $($ Debye $)$ & 2.68 \\
\hline
\end{tabular}


Table 2. Kinetic constants of phenol degradation by BRP-CLEAs in aqueous phase and silicone oil (47V20)

\begin{tabular}{cccc}
\hline Solvent & $K_{m}$ & $\begin{array}{c}V_{\max } \\
(\mathrm{mg} / \mathrm{L})\end{array}$ & $\begin{array}{c}V_{\max } / K_{m} \\
(1 / \mathrm{min})\end{array}$ \\
\hline Phosphate buffer (pH 7) & 92.28 & 2.22 & 0.024 \\
Silicone oil (47V20) & 62.03 & 0.32 & 0.005
\end{tabular}


Table 3. Optimal conditions for phenol removal by BRP-CLEAs in aqueous and organic media

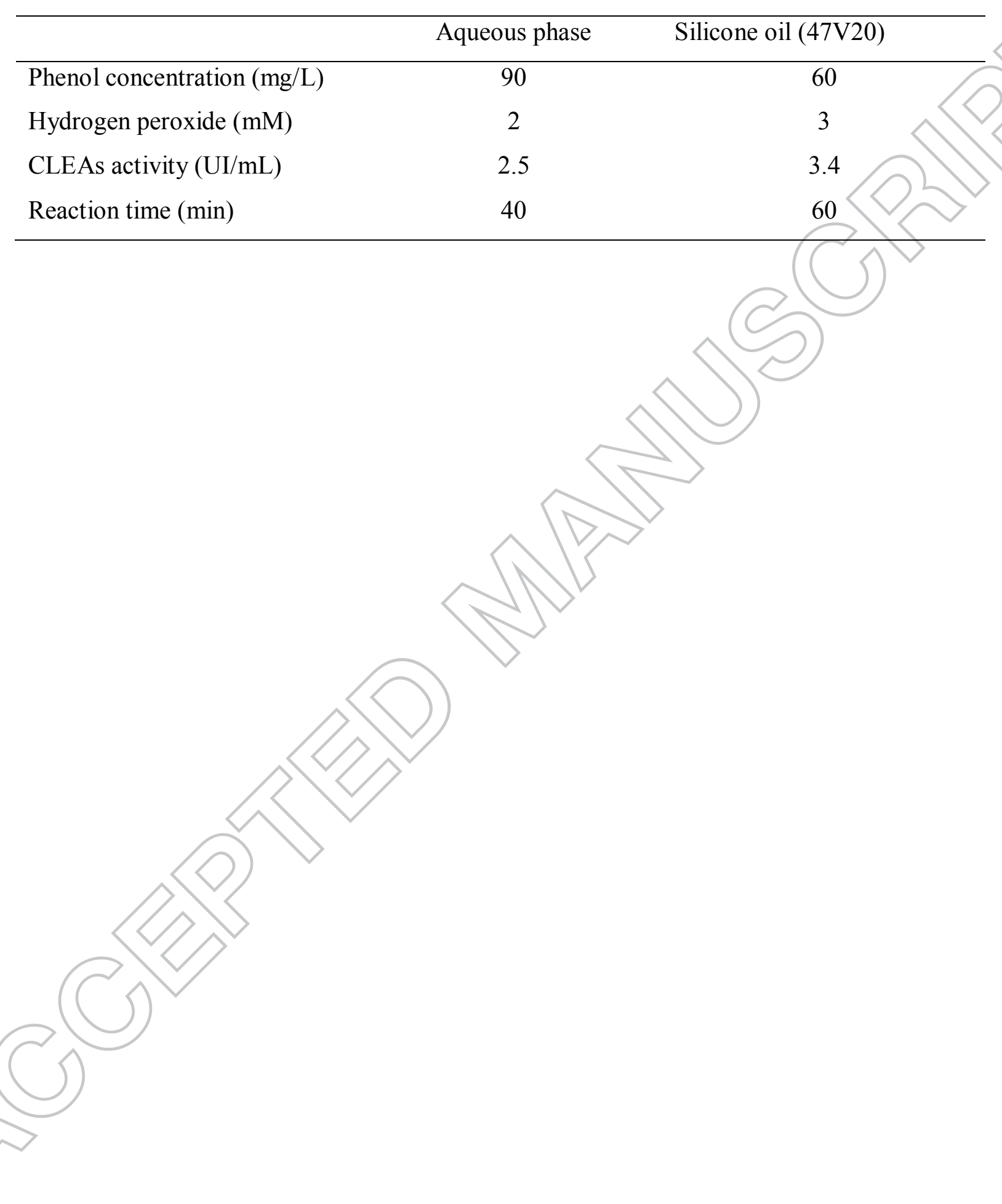

